(C) 2015

Колич Н. Б., кандидат ветеринарних наук

Національний університет біоресурсів і природокористування України

Скрипка М. В., доктор ветеринарних наук

Полтавська державна аграрна академія

\title{
ДО ОСОБЛИВОСТЕЙ ЛІМФАТИЧНОГО РУСЛА ТРАВНОЇ ТРУБКИ ДРІБНОЇ РОГАТОЇ ХУДОБИ
}

\section{Рецензент - доктор ветеринарних наук А. А. Замазій}

Від слизової оболонки різних ділянок ротової порожнини відтік лімфи здійснюється поверхневим $i$ глибокими лімфатичними судинами в ретіонарні лімфовузли. Слизова та м'язова оболонки передшлунків має добре розвинене лімфатичне русло, щзо складається зі звивистих капілярів зі сліпими виростами. У серозній оболонці розташовуються лімфатичні капіляри з колбоподібними виступами. Капіляри, з'єднуючись між собою, формують капілярну сітку. Відтік лімфи з ретіонарних лімфатичних вузлів книжки до $70 \%$ завершуються в передилунковому лімфатичному вузлі.

Ключові слова: лімфатичні судини, капіляри, лімфатичні вузли, рубець, книжка, сичуг, стравохід.

Постановка проблеми. Лімфатична система в організмі людини та тварин бере участь у багатьох життєвих процесах. Лімфатична система $\epsilon$ потужним біологічним бар'єром для збудників інфекційних захворювань. Відомо, що інфекційний агент, в залежності від його патогенності, 3 первинного вогнища переважно розповсюджується лімфогенним шляхом. Знання топографії та морфології лімфатичної системи необхідне анатомам, фізіологам, клініцистам, хірургам, онкологам, патологоанатомам, ветеринарносанітарним експертам у зв'язку з тим, що саме вони в своїй практичній діяльності частіше за все спираються на точні знання відтоку лімфи.

Аналіз основних досліджень і публікацій, у яких започатковано розв'язання проблеми. У капілярній мережі лімфатичної системи здійснюється всмоктування і транспортування колоїдних розчинів білків, ліпідів, тих, які в силу величини молекул не можуть проходити через стінку кровоносних капілярів, всмоктування хімусу 3 ворсинок тонкого відділу кишечника і знешкодження чужих і шкідливо діючих на організм речовин, які надходять туди різними шляхами (віруси i їх токсини, мікроби і їх токсини, личинки паразитів, хімічні речовини та ін.). Лімфатична система бере участь в обміні речовин, у транс- порті гормонів, ферментів, вітамінів, живленні тканин [1].

В останні роки вирішуються питання впливу різних лікарських засобів на розвиток патологічного процесу і хвороби за допомогою ендолімфатичної терапії. Застосовується ендолімфатичне введення лікарських препаратів, стимуляція лімфатичного дренажу тканин, дренування грудного лімфатичного протоку, ендолімфатичний вплив на імунні функції організму. Причому ендолімфатичне введення високомолекулярних лікарських речовин, на відміну від істинних розчинів, має на увазі їх затримку в лімфатичних судинах і лімфатичних вузлах, відсутність проникнення в кров, окрім гирла грудного протоку, а в умовах катетеризації останнього, виведення ïх «надлишків» 3 організму [9].

Мета досліджень: визначення особливостей морфології та топографії лімфатичного русла травної трубки дрібної рогатої худоби (вівці, кози) за результатом власних досліджень та опрацювання повідомлень науковців різних країн.

Завдання роботи: встановити особливості морфології і топографії лімфатичного русла травної трубки у дрібної рогатої худоби.

Матеріали і методи досліджень. Дослідження лімфатичної системи проводилося на трупному i боєнському матеріалі шляхом препарування, морфометрії, фотографування. Застосовувався метод внутрішньотканинної ін'єкції, виготовлення просвітлених препаратів, гістологічних зрізів.

Результати досліджень. Від слизової оболонки різних ділянок ротової порожнини і язика здорових тварин відтік лімфи здійснюється поверхневими і глибокими лімфатичними судинами в регіонарні лімфовузли. Від слизової оболонки губ, ясен і щік лімфа відводиться у підщелепний i привушний лімфовузли відповідної сторони. Відтік лімфи від слизової оболонки заднього відділу щоки і ясен йде в підщелепний і латеральний заглотковий лімфовузли, а від останнього в трахеальний лімфатичний проток. Відвідні лім- 


\section{ВЕТЕРИНАРНА МЕДИЦИНА}

фатичні судини слизової оболонки язика частіше вливаються в латеральний заглотковий, рідше в підщелепний лімфовузли, а від кореня язика i ясен корінних зубів - у медіальні заглоткові лімфовузли. Лімфатичні судини шийної частини стравоходу впадають безпосередньо в глибокі шийні лімфатичні вузли і в стравохідний лімфатичний стовбур. Відтік лімфи 3 початкової частини стравоходу відбувається в краніальні глибокі шийні і заглоткові лімфатичні вузли. Iз середньої третини шийної частини стравоходу лімфа відтікає по лімфатичних судинах, утворюючи стравохідний лімфатичний стовбур. Із задньої третини шийної частини стравоходу і грудної його частини лімфатичні судини по латеральній поверхні стравоходу прямують до каудальних шийних i бронхіальних лімфатичних вузлів. Краніальні глибокі шийні лімфатичні вузли розташовуються біля краніального кінця шиї з боків глотки, а група глибоких каудальних шийних, що складається 3 одного-трьох вузлів, розташовується на сагітальній поверхні трахеї безпосередньо біля входу в грудну порожнину $[3,7,8]$.

Лімфатична сітка діафрагмального відділу стравоходу тісно пов'язана 3 лімфатичною сіткою переддвір'я рубця. Під час пошарового дослідження стінки стравоходу з'ясувалося: лімфатична мережа підслизової основи має сіткоподібну будову i тісно пов'язана з лімфатичною системою м'язового шару, вона має переважно поздовжній напрямок лімфатичних судин і лімфовідток з неї відбувається до певних регіонарних лімфатичних вузлів. Слизова оболонка стравоходу також має добре розвинену лімфатичну сітку, тісно пов'язану з лімфатичною мережею підслизової основи [8].

Під епітелієм сосочків рубця є лімфатичні капіляри, які утворюють розгалужену мережу. Площа цієї мережі варіює в прямій відповідності 3 площею слизової оболонки органу. Ця оболонка в рубці, сітці і книжці має добре розвинене лімфатичне русло, що складається з капілярів зі сліпими виростами. Лімфатичні капіляри утворюють сітку, яка розташовується у власному шарі слизової оболонки. Лімфатичні капіляри слизової оболонки передшлунків звивисті і, з'єднуючись між собою анастомозами, формують капілярну мережу, петлі якої овальної, неправильної овальної, прямокутної і полігональної форми. Джерелами лімфатичної системи м'язової оболонки передшлунків є злегка звивисті лімфатичні капіляри. Останні розташовуються в сполучній тканині між пучками м'язових волокон. Залягаючи в декількох, що лежать одна над одною, площинах i, утворюючи між собою анастомози, вони формують капілярну мережу, петлі якої частіше прямокутної, рідше витягнутої і овальної форми. У серозній оболонці передшлунків розташовуються лімфатичні капіляри 3 колбоподібними виступами. Капіляри, з'єднуючись між собою, формують капілярну сітку [5].

Лімфатичні судини рубця виникають у разі злиття кількох лімфатичних посткапілярів або $є$ продовженням їхніх сіток i, залягаючи у всіх оболонках рубця, мають свої топографоморфологічні особливості. У результаті з'єднання лімфатичних посткапілярів підслизової основи рубця, утворюються лімфатичні судини першого порядку, що іноді формують сплетіння. Парні лімфатичні судини першого порядку, зливаючись, утворюють лімфатичні судини другого порядку, які після свого виникнення на досить великій відстані йдуть між поздовжнім і циркулярним шарами м'язової оболонки, потім, пронизуючи останній, вливаються в лімфатичне русло серозної оболонки. У лімфатичні судини першого, другого порядку підслизової основи рубця на всьому їхньому шляху вливаються лімфатичні капіляри, посткапіляри і судини від оточуючих ïx лімфатичних капілярних сіток i судинних сплетінь. Зі сплетіння лімфатичних посткапілярів м'язової оболонки рубця беруть початок лімфатичні судини першого порядку, які, з'єднуючись, формують лімфатичні судини другого порядку. Лімфатичні судини першого порядку серозної оболонки рубця, анастомозуючи між собою, утворюють крупнопетлисті сітки. Останні, приймаючи висхідні лімфатичні судини м'язової оболонки, стають лімфатичними судинами другого порядку. Об'єднуючись з аналогічними судинами підслизового шару, вони формують лімфатичні судини третього порядку, які, сплітаючись, дають початок більш великим аферентним судинам [5, 7].

Необхідно відзначити, що ширина даної ланки лімфатичного русла рубця кіз позитивно корелюють із віком тварини, а максимальні зміни нами виявлені у віці від одного до шести місяців. 3 підвищенням порядку судини збільшується і їі ширина. Так, у дорослих кіз максимальну ширину - 1,425 мм мають лімфатичні судини третього порядку рубця, а найменшу - 0,502 мм лімфатичні судини першого порядку. Таким чином, внутрішньоорганні лімфатичні судини рубця кіз утворюються в результаті злиття між собою лімфатичних посткапілярів і діляться на судини трьох порядків. У підслизовій основі і м'язовому шарі рубця виявлені лімфатичні судини двох порядків, а серозна оболонка містить лімфатичні судини всіх трьох порядків. Діаметр даних судин 


\section{ВЕТЕРИНАРНА МЕДИЦИНА}

позитивно корелює з віком тварини і порядковістю судини. Аферентні лімфатичні судини рубця формуються за рахунок злиття лімфатичних судин III порядку і йдуть в різних напрямках до регіонарних лімфатичних вузлів рубця. Від парієтальної поверхні каудодорсального сліпого мішка відходять 3-8 парних і 2-5 непарних лімфатичних судин, зливаючись, вони утворюють однудві аферентні судини, які йдуть по правому повздовжньому жолобу. Прямуючи дорсокраніально, дані судини в більшості випадків (72,5\%) впадають в серединний або $(27,5$ \%) в передверні лімфатичні вузли рубця. Від вісцеральної поверхні каудодорсального сліпого мішка 2-3 парних і 37 непарних судин, з'єднуючись, дають початок великим аферентним судинам, що йдуть по лівому повздовжньому жолобу в краніовентральному напрямку. Інша частина лімфатичних судин із вісцеральної поверхні каудодорсального мішка через його дорсальну кривизну переходить на париєтальну поверхню і впадає в аферентні судини, що йдуть в дорсальному вінцевому жолобі. Від парієтальної поверхні каудовентрального сліпого мішка 2-6 парних і 2-5 непарних судин, досягаючи правого вентрального вінцевого жолобу, формують більш великі 1-3 аферентних судини, що йдуть в дорсокраніальному напрямку в правий повздовжній жолоб і вливаються в правосторонній серединний лімфатичний вузол рубця [2, 3, 7].

Від вісцеральної поверхні каудовентрального сліпого мішка відходять 3-5 парних і 2-6 непарних лімфатичних судин, які далі зливаються між собою у великі 1-2 аферентні судини, що йдуть у каудодорсальному напрямку до лівого вентрального вінцевого жолобу.

Від каудальної половини парієтальної поверхні дорсального мішка 3-5 парних і 2-4 непарних аферентні лімфатичні судини направляються до повздовжнього жолобу рубця. Далі вони зливаються в більш ширші 1-2 аферентні судини, які впадають у правосторонній серединний лімфатичний вузол рубця.

Від краніальної половини парієтальної поверхні дорсального мішка відходять 2-6 парних і 14 непарні лімфатичні судини, які, з'єднуючись, утворюють 1-3 великих аферентних судини, що йдуть або в вентральному напрямку до правого повздовжнього жолобу, або проходять краніовентрально по парієтальній поверхні дорсального мішка рубця і вливаються в краніальні рубцеві лімфовузли.

3 вісцеральної поверхні дорсального мішка 59 парних і 4-8 непарних дрібних аферентних лімфатичних судин у краніовентральному напрям- ку йдуть до краніального жолобу рубця, об'єднуються 3 однотипними лімфатичними судинами, що відходять від краніальної половини вісцеральної поверхні вентрального мішка і формують 1-3 великі аферентні судини. Частина судин третього порядку з вісцеральної поверхні дорсального мішка рубця переходить через його дорсальну кривизну на парієтальну поверхню i, з'єднуючись 3 іншими судинами, дає початок 1-2 аферентним судинам.

У 27,3 \% випадків 1-2 аферентні судини від краніального вузла книжки завершуються в передшлунковому лімфатичному вузлі. На 10,9\% еферентні судини краніального лімфатичного вузла, разом 3 еферентними судинами передшлунків і правих рубцевих лімфовузлів, беруть участь в утворенні шлункового лімфатичного стовбура. Крім того, в 3,7 \% випадків одна аферентна судина від краніального вузла книжки вливається в правосторонні краніальні вузли сітки. Від фундальних лімфатичних вузлів книжки 1-3 еферентні судини в 70,9 \% випадків вливаються в краніальні вузли книжки, а в 29,1\% ці судини відводять лімфу в передшлунковий лімфатичний вузол [2, 4, 6].

Встановлено, що лімфатичне русло сичуга кози представлено капілярами, що залягають у всіх оболонках органу, посткапілярами і судинами першого, другого i третього порядків. Основою лімфатичної системи слизової оболонки всіх відділів сичуга є синусоїдні лімфатичні капіляри, які біля поверхні слизової оболонки мають булавовидні розширення. Найбільша кількість синусоїдних капілярів знаходиться в слизовій оболонці малої кривизни сичуга і менша їх кількість - в області великої кривизни даного органу [7].

\section{Висновки:}

1. Від слизової оболонки різних ділянок ротової порожнини і язика дрібної рогатої худоби відтік лімфи здійснюється поверхневим і глибокими лімфатичними судинами в регіонарні лімфовузли (підщелепний, привушний, заглотковий).

2. Лімфатичні судини шийної частини стравоходу впадають безпосередньо в глибокі шийні лімфатичні вузли (краніальні глибокі шийні, заглоткові, каудальні шийні і бронхіальні) і в стравохідний лімфатичний стовбур.

3. Слизова та м'язова оболонки передшлунків має добре розвинене лімфатичне русло, що складається зі звивистих капілярів зі сліпими виростами. У серозній оболонці розташовуються лімфатичні капіляри 3 колбоподібними виступами. Капіляри, з'єднуючись між собою, формують капілярну сітку. 


\section{ВЕТЕРИНАРНА МЕДИЦИНА}

4. Відтік лімфи з регіонарних лімфатичних вузлів книжки у 27,3 \% випадків завершуються в передшлунковому лімфатичному вузлі. Від фундальних лімфатичних вузлів книжки 1-3 еферен-

\section{БІБЛІОГРАФІЯ}

1. Бородин Ю. И. Общая анатомия лимфатической системы / Ю. И. Бородин, М. Р. Сапин, Л. Е. Этинген. - Новосибирск, 1990. - 243 с.

2. Джайнаров Б. Д. Возрастные особенности лимфатических узлов и сосудов преджелудков и сычуга каракульских овец : автореф. дисс. на соиск. уч. степени к. вет. н. : спец. 16.00.02 «Патология, онкология и морфология животных» / Б. Д. Джайнаров. - Самарканд, 1979. - 19 с.

3. Иосифов И. М. Лимфатическая система овцы / И. М Иосифов // Тр. Горского с/х ин-та. Т. 5. - Дзауджикау, 1945. - С. 167-171.

4. Нарзиев Д. Х. Возрастные особенности лимфатической системы желудка и пути оттока у каракульских овец / Д. Х. Нарзиев, Б. Жайнаров. Московское общество испытателей природы // Влияние экологических факторов на морфофункциональное состояние внутренних органов животных. - М., 1986. - С. 48-50.

5. Окунев Д. А. Интраорганное лимфатическое русло сетки оренбургской козы / Д. А. Окунев, тні судини в 70,9 \% випадків вливаються в краніальні вузли книжки, а в 29,1 \% ці судини відводять лімфу в передшлунковий лімфатичний вузол.

Р. Ш. Тайгузин // Известия Оренбургского ГАУ. 2008. - №4 (20). - C. 124-127.

6. Складнева Е. Ю. Внутриорганное лимфатическое русло книжки овцы красноярской тонкорунной породы. Достижения ветеринарной медицины - XXI века : материалы Междунар. науч. конф. ; сб. науч. тр. / Е. Ю. Складнева. - Барнаул, 2002. - C. 145-147.

7. Тайгузин Р. Ш. Строение лимфатического русла головы и некоторых органов оренбургской козы / Р. Ш. Тайгузин, Д. А. Окунев, Э. Г. Хабибуллин // Известия Оренбургского государственного аграрного университета. - 2008. - №2 (18). C. $114-117$.

8. Чумаков В. Ю. Пути оттока лимфы из пищевода овец / В. Ю. Чумаков, Е. М. Назарова, В. М. Романов // Современные проблемы науки и образования. - 2005. - №2. - С. 45-48.

9. Чумаков В. Ю. Эндолимфатическая терапия в ветеринарии / В. Ю. Чумаков // Ветеринария. 1997. - №8. - C. 41. 